Int. J. Electrochem. Sci., 15 (2020) 10007 - 10027

\title{
Conductivity Properties of Selected Aliphatic Monocarboxylic Acid Anions in Water at 298.15 K
}

\author{
Zdzisław Kinart ${ }^{1, *}$ and Renato Tomaš ${ }^{2, *}$ \\ ${ }^{1}$ Department of Physical Chemsitry, Faculty of Chemsitry, University of Lodz, 90-236 Lodz, \\ Pomorska 163/165, Poland \\ ${ }^{2}$ Department of Physical Chemsitry, Faculty of Chemistry and Technology, University of Split, \\ Ruđera Boškovića 35, HR-21000 Split, Croatia \\ *E-mail: zdzislaw.kinart@ chemia.uni.lodz.pl, rtomas@ktf-split.hr
}

doi: $10.20964 / 2020.10 .68$

Received: 3 July 2020 / Accepted: 13 August 2020 / Published: 31 August 2020

The article presents the electric conductivity values of sodium salts of four selected monocarboxylic acid derivatives in aqueous solution: those with a chlorine substituent in the peripheral position, i.e. $\mathrm{ClCH}\left(\mathrm{CH}_{2}\right)_{\mathrm{n}} \mathrm{COOH}$; those with a bromine substituent in the peripheral position, i.e. $\mathrm{BrCH}\left(\mathrm{CH}_{2}\right)_{\mathrm{n}} \mathrm{COOH}$; as well as unsaturated sodium salts with a double bond in the peripheral position, i.e. $\mathrm{CH}_{2}=\mathrm{CH}\left(\mathrm{CH}_{2}\right)_{n} \mathrm{COOH}$; and unsaturated sodium salts with a double bond in the second position, i.e. $\mathrm{CH}_{3}-\mathrm{CH}=\mathrm{CH}\left(\mathrm{CH}_{2}\right)_{\mathrm{n}} \mathrm{COOH}$. All conductivity measurements were performed at $298.15 \mathrm{~K}$ in the concentration range of $0.0005<c / \mathrm{mol} \cdot \mathrm{dm}^{-3}<0.018$. The obtained values allowed the limiting molar conductivities $\left(\Lambda_{m}^{0}\right)$ of the studied electrolytes to be determined using the Fuoss-Justice equation. Based on these $\left(\Lambda_{m}^{0}\right)$ values, the molar limiting conductivity values $\left(\lambda_{A^{-}}^{0}\right)$ for individual anions of the tested electrolytes were calculated and analyzed as a function of carbon chain length. The work also examines the effect of substituent type $(\mathrm{Cl}$ or $\mathrm{Br})$ and double bond location on the limiting molar conductivity values of the tested monocarboxylic acid anions and compares them with literature values.

Keywords: Molar conductivity, sodium salts of unsaturated carboxylic acids, sodium salts of monocarboxylic acids with $\mathrm{Cl}$ and $\mathrm{Br}$ substituents.

\section{$\underline{\text { FULL TEXT }}$}

(C) 2020 The Authors. Published by ESG (www.electrochemsci.org). This article is an open access article distributed under the terms and conditions of the Creative Commons Attribution license (http://creativecommons.org/licenses/by/4.0/). 